\title{
Ammonium fixation and availability of fixed ammonium in some Dutch loam and clay soils
}

\author{
D. A. van Schreven
}

Biological Laboratory of the IJsselmeerpolders Development Authority, P.O. Box 5, Kampen, The Netherlands

Recieved 5 December, 1967

\begin{abstract}
Summary
Polder soils recently reclaimed from Lake IJssel generally fixed from 3 to 10 per cent of added ammonium nitrogen. Old river clays fixed up to 87 per cent of the applied ammonium nitrogen. The fixation of ammonium decreased with increasing potassium supplied in the field.

Fixation was completed within 24 hours when an aqueous solution of $\left(\mathrm{NH}_{4}\right)_{2} \mathrm{SO}_{4}$ was added both to a young polder soil with a clay fraction consisting mainly of common (Fithian) illite and to an old river clay soil at Nederhemert, taken from plots of a permanent trial field which for ten years had received annual applications of either 650 or $1000 \mathrm{~kg} \mathrm{~K}_{2} \mathrm{SO}_{4}$ per ha. Fixation took 72 hours to reach virtual completion in an old river clay soil with no recent history of potassium fertilization, known to be capable of fixing large quantities of potassium, and whose clay fraction was predominantly weathered illite (Ammersooite).

A heavy young polder soil supplied with $100 \mathrm{ppm}$ nitrogen as $\mathrm{NH}_{4} \mathrm{NO}_{3}$ or $\left(\mathrm{NH}_{4}\right)_{2} \mathrm{SO}_{4}$ fixed ammonium that was not recovered during incubation for 16 weeks. An old river clay that had not been dressed with potassium for 14 years also fixed ammonium added in similar concentration but much was nitrified during incubation for 16 weeks. When potassium was added to the old river clay either shortly before or after adding $\left(\mathrm{NH}_{4}\right)_{2} \mathrm{SO}_{4}$ the old illite behaved like young illite in that little or none of the fixed ammonium was available to nitrifying bacteria.
\end{abstract}

\section{Introduction}

Van der Marel $(1950,1954)$ found that particles smaller than $2 \mu$ in young river and marine soils in the Netherlands contain about 80 per cent common (Fithian) illite and do not fix important amounts of potassium. Several workers (Hudig and Duyverman, 1950; Hudig, 1950; Van der Marel and Venekamp, 1955) have observed that the original non-fixing alluvial illite clays develop a very high fixing capacity on weathering under certain conditions. According to Van der Marel and Venekamp (1955) the increased fixation capacity of old clays is due to the transformation of the common (Fithian) illite $(\mathrm{d}=10.8 \AA)$ to illite with open lattices (Ammersooite; $\mathrm{d}=15.6 \AA$ ).

As $\mathrm{K}^{+}$and $\mathrm{NH}_{4}+$ ions are probably fixed by the same mechanism (Chaminade, 1940 ; Page and Baver, 1939; Stanford and Pierre, 1946, and others) young loam and clay 
soils in the Netherlands may be expected to fix little and old river clays much added ammonium. Van Schreven $(1963,1964)$ verified the small $\mathrm{NH}_{4}$-fixation capacity of young polder soils derived from Lake IJssel compared with that of old marine clay polder soils and concluded that hundreds of years must elapse before such polder soils will be able to fix important amounts of added ammonium or potassium. Native fixed ammonium in recently reclaimed polder soils was also shown to be little available to nitrifying organisms and spring barley.

The present investigations were conducted (a) to compare ammonium fixation in a number of IJssel-lake polder soils with that in old river clay soils, (b) to study the effect of the time of reaction between the added ammonium nitrogen and the soil on the fixation process, and the effect of potassium on this process, (c) to determine the availability to nitrifying bacteria of ammonium ions fixed from ammonium salts added to young and old clay soils and the effect of added potassium on this process.

\section{Methods}

Ammonium nitrogen was extracted from both treated soil samples $(100 \mathrm{ppm} \mathrm{N}$ added as $\left(\mathrm{NH}_{4}\right)_{2} \mathrm{SO}_{4}$ on an oven-dry basis) and untreated samples by shaking $250 \mathrm{~g}$ of fresh soil with $600 \mathrm{ml} \mathrm{N} \mathrm{KCl}$ solution for two and a half hours. After allowing the suspension to stand overnight, the ammonium in the supernatant liquid was determined by distilling an aliquot with $\mathrm{MgO}$ and titrating the distilled ammonia with 0.01 or $0.002 \mathrm{~N}$ acid. The amount of $\mathrm{NH}_{4}+$ nitrogen which had been fixed after adding $\mathrm{NH}_{4}+$ nitrogen to the soil sample was calculated by substracting $\mathrm{NH}_{4}+$ nitrogen in the untreated sample from that extracted from the treated sample. The amount of total mineral nitrogen $\left(\mathrm{NH}_{4}++\mathrm{NO}_{2}-+\mathrm{NO}_{3}-\right)$ in the extract was determined by a modification of the method of Cotte and Kahane (1947); the amount of nitrate nitrogen was calculated by subtracting the amount of ammonium nitrogen found by distillation with 50 per cent $\mathrm{NaOH}$ (the same concentration as used for the determination of mineral nitrogen) from the total of mineral nitrogen.

In the experiments on the effect of time of reaction on the fixation of added $\mathrm{NH}_{4}+$ nitrogen the soil samples were kept at $29^{\circ} \mathrm{C}$ in closed $250-\mathrm{ml}$ bottles. The moisture content of the samples was maintained at 44,60 or 65 per cent of the water holding capacity (W.H.C.) as indicated in the text. To inhibit nitrification so that added ammonium-N remained in this form, toluene, sodium azide or monoiodacetic acid was added to the soil samples.

Each experiment consisted of three sets of incubated samples. One set was left without inhibitor, while the other two were treated with toluene $(50 \mathrm{~g}$ per $\mathrm{kg}$ dry soil), or with sodium azide to make the soil solution $\mathrm{M} / 300$, or with monoiodacetic acid ( $2 \mathrm{~g}$ per $\mathrm{kg}$ dry soil). Of these latter two sets, one was treated with $100 \mathrm{ppm}$ nitrogen as $\left(\mathrm{NH}_{4}\right)_{2} \mathrm{SO}_{4}$ on an oven-dry basis, the other was left without added nitrogen.

In the experiments on the availability of fixed ammonium ions to nitrifying bacteria, the soil samples, either untreated or treated with $100 \mathrm{mg} \mathrm{N}$ as $\mathrm{KNO}_{3}, \mathrm{NH}_{4} \mathrm{NO}_{3}$ or $\left(\mathrm{NH}_{4}\right)_{2} \mathrm{SO}_{4}$, were incubated in a humid atmosphere at $29^{\circ} \mathrm{C}$ for 16 weeks in $370-\mathrm{ml}$ jars closed with a lid having a small hole. The moisture content of these samples was checked regularly by weighing and kept as near to 65 per cent of the W.H.C. as possible. At regular intervals, triplicate samples were removed and nitrate, exchangeable ammonium and mineral nitrogen were extracted and determined. 


\section{Experimental and results}

Table 1 shows that young IJssel-lake polder soils fixed from 3 to 10 per cent of the $\mathrm{NH}_{4}+$ nitrogen added as a solution of $\left(\mathrm{NH}_{4}\right)_{2} \mathrm{SO}_{4}$ within 2 to 5 hours in the crystal lattice of the clay minerals. Old river clay soils, however, fixed from 26 to 57 per cent of the $\mathrm{NH}_{4}+$ nitrogen added. Fixation decreased with increasing potassium fertilizer applied on plots in the experimental field at Hedel.

Table 1 Fixation of ammonium nitrogen after addition of $100 \mathrm{ppm}$ nitrogen as (NH4) $\mathrm{SO}_{4}$ by a number of young polder soils and old river-clay soils (1961)

\begin{tabular}{|c|c|c|c|c|c|c|}
\hline $\begin{array}{l}\text { Soil } \\
\text { type }\end{array}$ & $\begin{array}{c}\text { Depth } \\
\text { of soil } \\
\text { layer, } \\
\mathrm{cm}\end{array}$ & Origin & $\begin{array}{c}\text { Year } \\
\text { of } \\
\text { recla- } \\
\text { mation }\end{array}$ & $\begin{array}{c}\mathrm{NH}_{4}+-\mathrm{N} \\
\text { originally } \\
\text { extractable } \\
(\text { ppm })\end{array}$ & $\begin{array}{c}\mathrm{NH}_{4}+-\mathrm{N} \\
\text { extractable } \\
\text { after } \\
\text { addition } \\
\text { of } 100 \mathrm{ppm} \\
\mathrm{NH}_{\mathbf{4}}+\mathrm{N}(\mathrm{ppm})\end{array}$ & $\begin{array}{l}\text { NHst-N } \\
\text { fixed } \\
\text { within } \\
2 \text { to } 5 \\
\text { hours } \\
\text { (\%) }\end{array}$ \\
\hline Loam & $0-20$ & Eastern Fle_- & 1957 & 0.4 & 96.2 & 4.2 \\
\hline " & $20-40$ & voland Polder & $"$ & 0.2 & 97.2 & 3.0 \\
\hline \multirow[t]{2}{*}{$"$} & $0-20$ & , & $"$ & 1.4 & 94.6 & 6.8 \\
\hline & $20-40$ & $"$ & $"$ & 0.3 & 96.2 & 4.1 \\
\hline Clay & $0-20$ & $"$ & $"$ & 1.4 & 94.6 & 6.8 \\
\hline & $20-40$ & & & 0.8 & 96.7 & 4.1 \\
\hline Sandy loam & $0-20$ & North-East & 1942 & 1.3 & 94.2 & 7.1 \\
\hline " & $20-40$ & polder & " & 0.6 & 92.7 & 7.9 \\
\hline Loam & $0-20$ & porater & $"$ & 0.6 & 90.5 & 10.1 \\
\hline Clay & $0-20$ & ", & " & 3.6 & 95.2 & 8.4 \\
\hline Old river clay & $5-25$ & Hedel a) * & $"$ & 3.2 & 45.0 & 57.1 \\
\hline " " " & $5-25$ & , b) & - & 2.6 & 51.6 & 51.0 \\
\hline$"$ & $5-25$ & " & - & 2.1 & 57.5 & 44.4 \\
\hline$"$ & $5-25$ & " d) & - & 0.0 & 74.2 & 25.8 \\
\hline ," & $0-20$ & Kesteren & - & 5.0 & 69.1 & 35.9 \\
\hline
\end{tabular}

* The river clay samples of Hedel were taken in 1961 from plots of a permanent experimental field that was laid out in 1947 . The plots a), b), c) and d) had received annually $0,300,600$ and $900 \mathrm{~kg} \mathrm{~K}_{2} \mathrm{SO}_{4}$ per ha, respectively.

Effect of time of reaction between the added ammonium nitrogen and the soil on the fixation process

Jansson (1958) showed that although soils fixed most of the $\mathrm{NH}_{4}+$ nitrogen immediately, fixation generally continued slowly for the first 24 hours and sometimes for 6 to 17 days.

In the present experiment the effects of time of reaction between the added $\mathrm{NH}_{4}+$ nitrogen and the soil on the fixation process were investigated using a young calcareous loam soil (parcel P 109 from the North-East polder) and some old river clay soils with a slightly acid reaction $\left(\mathrm{pH}-\mathrm{H}_{2} \mathrm{O}=6.8\right)$.

In order to prevent losses of nitrogen as ammonia that may occur when ammonium salts are applied to the surface of calcareous polder soils (Van Schreven, 1950, 1955), the ammonium sulphate was pipetted as an aqueous solution into the centre of the soil samples in the bottles. The samples were then stirred thoroughly and the bottles were stoppered immediately. 
Table 2 Influence of time of reaction between ammonium nitrogen and a loam soil of parcel P 109 from the North-East polder on the fixation of ammonium

\begin{tabular}{|c|c|c|c|c|c|c|c|c|c|c|c|}
\hline \multirow{2}{*}{$\begin{array}{l}\text { Time } \\
\text { of } \\
\text { reaction }\end{array}$} & \multicolumn{3}{|c|}{ Untreated soil } & \multicolumn{3}{|c|}{ Soil + toluene } & \multicolumn{3}{|c|}{$\begin{array}{l}\text { Soil }+ \text { toluene }+ \\
100 \mathrm{ppm} \mathrm{NH}+-N\end{array}$} & \multicolumn{2}{|c|}{$p p m$} \\
\hline & $\begin{array}{c}p p m \\
\text { exch. } \\
N H_{a}+-N\end{array}$ & $\begin{array}{c}p p m \\
\mathrm{NO}_{3}-\mathrm{N}\end{array}$ & $\begin{array}{c}p p m \\
\min \\
N\end{array}$ & $\begin{array}{c}p p m \\
\text { exch. } \\
N H_{4}+-N\end{array}$ & $\begin{array}{c}p p m \\
\mathrm{NO}_{3}-\mathrm{N}\end{array}$ & $\begin{array}{c}p p m \\
\min \\
N\end{array}$ & $\begin{array}{c}p p m \\
\text { exch. } \\
N H_{a}+-N\end{array}$ & $\underset{N O_{3} \rightarrow-N}{p p m}$ & $\begin{array}{c}p p m \\
\min \\
N\end{array}$ & $\begin{array}{c}\mathrm{NH}_{4}+-\mathrm{N} \\
I^{*}\end{array}$ & $\begin{array}{c}\text { fixed } \\
I I *\end{array}$ \\
\hline $0 \mathrm{hr}$ & 3.9 & 11.7 & 15.6 & 3.9 & 11.7 & 15.6 & 94.6 & 11.1 & 105.7 & 9.3 & 9.9 \\
\hline $6 \mathrm{hrs}$ & 3.9 & 11.7 & 15.6 & 3.9 & 11.7 & 15.6 & 94.6 & 11.0 & 105.6 & 9.3 & 10.0 \\
\hline $24 "$ & 4.0 & 12.6 & 16.6 & 4.0 & 12.0 & 16.0 & 94.6 & 11.0 & 105.6 & 10.4 & 10.1 \\
\hline 48 & 3.1 & 15.2 & 18.3 & 6.7 & 10.1 & 16.8 & 95.8 & 10.4 & 107.2 & 10.9 & 10.6 \\
\hline $80 "$ & 1.4 & 19.2 & 20.6 & 8.4 & 9.1 & 17.5 & 97.8 & 10.5 & 108.3 & 10.6 & 9.2 \\
\hline 5 days & 0.5 & 21.1 & 21.6 & 9.0 & 11.4 & 20.4 & 97.9 & 10.1 & 108.0 & 11.1 & 12.4 \\
\hline $15 \%$ & 0.8 & 26.0 & 26.8 & 35.3 & 6.3 & 41.6 & 124.3 & 5.9 & 130.2 & 11.0 & 11.4 \\
\hline
\end{tabular}

* The method used for estimates $\mathrm{I}$ and II of $\mathrm{NH}_{4}+$ fixation is described in the text.

Results obtained with a young clay soil from the North-East polder treated with toluene. The soil samples were kept at 65 per cent of the W.H.C. and toluene was added as an agent to inhibit nitrification. In the untreated and treated samples, exchangeable ammonium, nitrate and mineral nitrogen were determined at the time intervals mentioned in Table 2 . The first determination was performed immediately after the treatment was completed. The data presented in Table 2 show that in the presence of toluene, nitrification was inhibited during the period of incubation in contrast to ammonification which became apparent already after 48 hours. After 15 days, the amount of mineral nitrogen present in the sample treated with toluene that had not been enriched with nitrogen was even larger than that in the untreated sample. In short-term incubation experiments, Russell and Hutchinson (1909, 1913), Russell and Golding (1913), Russell and Petherbridge (1913), Waksman and Starkey (1923) found earlier that toluene treatment of soil may lead to an accumulation of ammonium.

Estimates of $\mathrm{NH}_{4}+$ fixation were obtained in two ways, namely by determining difference in either $\mathrm{NH}_{4}+$ nitrogen (I) or total mineral nitrogen (II) between samples treated with toluene with and without $\left(\mathrm{NH}_{4}\right)_{2} \mathrm{SO}_{4}$. In general the estimates I and II agreed quite well (Table 2).

A little more ammonium was fixed after 5 days and 15 days than after 24 hours. To find whether this slight increase was partly or wholly due to volatilisation of

Table 3 Loss of nitrogen in ppm due to evaporation of ammonia (300 $\mathrm{g}$ soil treated with $100 \mathrm{ppm} N$ as $\left(\mathrm{NH}_{4}\right)_{2} \mathrm{SO}_{4}+100 \mathrm{ppm}$ sodium azide)

\begin{tabular}{|c|c|c|c|c|}
\hline \multirow[t]{2}{*}{ Bottle } & \multicolumn{4}{|c|}{ Time of reaction } \\
\hline & $2 \mathrm{hrs}$ & $24 \mathrm{hrs}$ & 5 days & 15 days \\
\hline $\begin{array}{l}1 \\
2 \\
3\end{array}$ & $\left.\begin{array}{l}0.05 \\
0.03 \\
0.03\end{array}\right\} 0.04$ & $\left.\begin{array}{l}0.10 \\
0.09 \\
0.13\end{array}\right\} 0.11$ & $\left.\begin{array}{l}0.42 \\
0.58 \\
0.44\end{array}\right\} 0.48$ & $\left.\begin{array}{l}0.78 \\
0.61 \\
0.72\end{array}\right\} 0.70$ \\
\hline
\end{tabular}


ammonia, an additional experiment was done in which soil samples were aerated during incubation. Ammonia-free moist air was passed over the soil surface and led afterwards through $0.1 \mathrm{~N} \mathrm{HCl}$. The ammonia was determined colorimatrically at intervals. Since much toluene would evaporate from the soil during aeration, $100 \mathrm{ppm}$ sodium azide were added to the soil which inhibited nitrification for at least 15 days. Table 3 shows that a little nitrogen was lost as ammonia. When results in the original experiment were corrected for these losses, ammonium fixation was found to be completed within 24 hours.

Results obtained with a clay-loam soil from the North-East polder treated with sodium azide. Lees and Porteous (1950) found that sodium azide added to soil inhibits nitrification. Jansson (1958) showed that nitrification was inhibited for at least 52 days when sodium azide was added to make the soil solution $M / 330$. Vlassak (1962) found that $650 \mathrm{ppm}$ sodium azide decreased mineralisation and inhibited nitrification for 30 days.

In the present experiment sufficient sodium azide was added to a loam soil (parcel P 107 from the North-East polder) to make the soil solution $\mathrm{M} / 300$. An aqueous solution supplying $100 \mathrm{mg}$ nitrogen per $\mathrm{kg}$ of dry soil as $\left(\mathrm{NH}_{4}\right)_{2} \mathrm{SO}_{4}$ was added to one or two sets treated with azide; the other was not supplied with ammonium nitrogen. The soils in jars closed with a lid provided with a small hole were incubated at a moisture content of 44 per cent of the W.H.C. Exchangeable ammonium, nitrate and mineral nitrogen were determined immediately after the treatment was completed, and after 2 and 24 hours and after 5, 15, 30, 50 and 85 days, respectively. Figure 1 shows that after 2 and 24 hours, 8.5 and $10.1 \mathrm{ppm}$ ammonium nitrogen

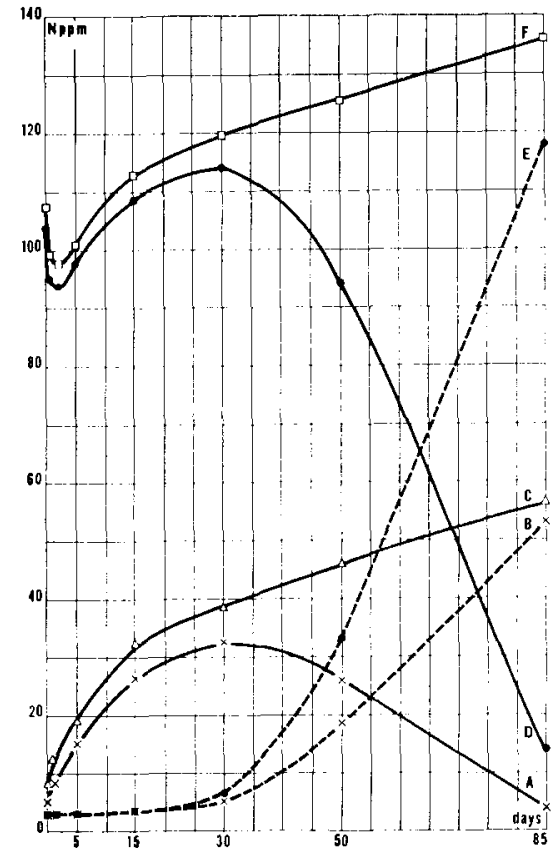

Fig. 1 Total non-fixed mineral nitrogen (lines $C$ and $F$ ), exchangeable ammonium nitrogen (lines $A$ and $D$ ) and nitrite + nitrate nitrogen (lines $B$ and $E$ ) in $a$ loam soil of the North-East polder (treated with sodium azide) without $N$ and with addition of $100 \mathrm{ppm}$ $\mathrm{N}$ as $\left(\mathrm{NH}_{4}\right)_{2} \mathrm{SO}_{4}$ and incubated for 85 days at $29^{\circ} \mathrm{C}$. $A, B$ and $C=$ soil without nitrogen; $D, E$ and $F=$ soil with nitrogen. 
were fixed, respectively, and that nitrification in the soil treated with azide was almost entirely suppressed for the first 25 days. In contrast to the results of Jansson (1958) and Vlassak (1962) soil treated with azide mineralised more nitrogen than did the untreated soil (not presented in Fig. 1).

Results obtained with an old potassium-fixing river clay soil from De Vlierd. In the present experiment, an old river clay soil from De Vlierd with no recent history of potassium fertilization was used, which was known to be capable of fixing large quantities of potassium. Monoiodacetic acid was used to inhibit nitrification. Vlassak (1962) found that treating soil with monoiodacetic acid before incubating, for 30 days decreased mineralisation of soil organic nitrogen by about 80 per cent and inhibited nitrification completely.

The following treatments were compared:

1. $250 \mathrm{~g}$ untreated soil per bottle;

2. do. $+500 \mathrm{mg}$ monoiodacetic acid;

3. as $2+100 \mathrm{ppm}$ nitrogen as $\left(\mathrm{NH}_{4}\right)_{2} \mathrm{SO}_{4}$.

Monoiodacetic acid and $\left(\mathrm{NH}_{4}\right)_{2} \mathrm{SO}_{4}$ were added in aqueous solutions to soils in $150-\mathrm{ml}$ bottles. Soil samples were brought to 60 per cent of the W.H.C., and kept in stoppered bottles at $29^{\circ} \mathrm{C}$. Exchangeable ammonium, nitrate and mineral nitrogen were determined after incubating for 5 minutes, 2 hours, 24 hours, 72 hours, 7 days, 15 days and 30 days. Estimates of fixed ammonium were calculated in the same way as in the preceding experiments.

Adding monoiodacetic acid entirely inhibited mineralisation and nitrification in this soil for 30 days. Although about three quarters of the $\mathrm{NH}_{4}+$ added was fixed within 5 minutes, fixation continued for 72 hours (Fig. 2, curve A). Since the soil was slightly acid the increase in ammonium fixation in the first 72 hours is unlikely to be due to losses of nitrogen by volatilisation of ammonia. After 72 hours this soil fixed 87 per cent of the applied ammonium nitrogen.

Results obtained with an old river clay soil from Nederhemert. Samples used were taken from plots of a permanent trial field at Nederhemert, which for 10 years had received annual applications of $250,450,650$ or $1000 \mathrm{~kg} \mathrm{~K}_{2} \mathrm{SO}_{4}$ per ha. The same

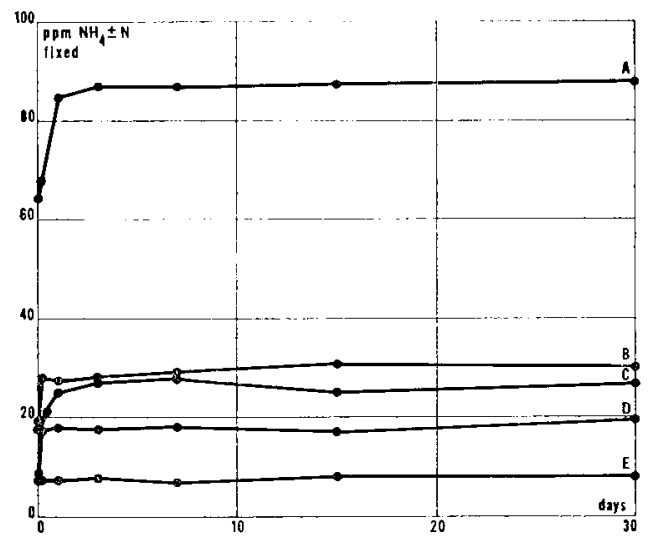

Fig. 2 Influence of time of reaction on the amount of fixed ammonium nitrogen in old river clay soils in the presence of monoiodacetic-acid.

$A=$ soil from de Vlierd with no potassium fertilizer; $B, C, D$ and $E=$ soil from plots of a trial field at Nederhemert which for 10 years received annual applications $o$. $250,450,650$ or $1000 \mathrm{~kg} \mathrm{~K} \mathrm{~K}_{2} \mathrm{SO}$, per ha respectivety. 
procedure was followed as in the preceding experiment. The results are presented in Figure 2 (curves $\mathrm{B}, \mathrm{C}, \mathrm{D}$ and $\mathrm{E}$ ).

Adding monoiodacetic acid inhibited nitrification for 30 days, but did not entirely suppress mineralisation. Figure 2 shows that quantity of $\mathrm{NH}_{4}+$ fixation is inversely correlated and that speed of fixation is directly correlated with quantity of $\mathrm{K}$ applied. In contrast to the soil of the Vlierd (preceding section) which had never been dressed with potassium, treating the soils with the higher rates of potassium both shortened the fixation period and decreased the amount fixed. Soil from the heavily fertilised plots behaved like a young soil of the North-East polder.

Availability of ammonium nitrogen fixed by a young polder soil to nitrifying organisms A calcareous heavy loam from parcel J 135 of the North-East polder was treated as follows:

1. A part was left untreated;

2. A part was treated with $100 \mathrm{ppm} \mathrm{N}$ as $\mathrm{KNO}_{3}$;

3. A part was treated with $100 \mathrm{ppm} \mathrm{N}$ as $\mathrm{NH}_{4} \mathrm{NO}_{3}$;

4. A part was treated with $100 \mathrm{ppm} \mathrm{N}$ as $\left(\mathrm{NH}_{4}\right)_{2} \mathrm{SO}_{4}$.

The soil originally contained 5 ppm ammonium and 5 ppm nitrate nitrogen on a dry-soil basis. Twenty four hours after adding $100 \mathrm{ppm} \mathrm{N}$ as $\mathrm{KNO}_{3}, 110 \mathrm{ppm}$ mineral nitrogen were recovered so that $100 \mathrm{ppm}$ nitrate nitrogen were recovered quantitatively. Similarly, $95 \mathrm{ppm} \mathrm{N}$ added as $\mathrm{NH}_{4} \mathrm{NO}_{3}$ and $90 \mathrm{ppm} \mathrm{N}$ as $\left(\mathrm{NH}_{4}\right)_{2} \mathrm{SO}_{4}$ were recovered so that 5 and $10 \mathrm{ppm} \mathrm{N}$ of the ammonium nitrogen were fixed corresponding to 10 per cent of that added in each form.

Afterwards the samples were incubated for 16 weeks, at a moisture content of 65 per cent of the W.H.C. Exchangeable ammonium and nitrate nitrogen were determined at intervals of 2 weeks.

Fig. 3 shows that all the exchangeable ammonium present at the start had been nitrified within 2 weeks. Apparently the fixed ammonium was not recovered (the four mineralisation curves run parallel to each other over the full 16-week incubation period). If the fixed ammonium would have been released the curves belonging to the samples amended with $\mathrm{NH}_{4} \mathrm{NO}_{3}$ or $\left(\mathrm{NH}_{4}\right)_{2} \mathrm{SO}_{4}$ would have approached the curve of the sample treated with $\mathrm{KNO}_{3}$.

A vailability of ammonium nitrogen fixed by old river clay soils to nitrifying organisms The presence of small amounts of potassium is known to interfere with the release of fixed ammonium (Allison et al., 1951, 1953; Nômmik, 1957) so that fixed ammonium may be protected from the action of nitrifying bacteria.

Soil was taken from a plot of the permanent field at Hedel that for 14 years had not received potassium fertilizer. Samples of this soil were treated with (1) $100 \mathrm{ppm} \mathrm{N}$ as $\mathrm{KNO}_{3}$, (2) $100 \mathrm{ppm} \mathrm{N}$ as $\left(\mathrm{NH}_{4}\right)_{2} \mathrm{SO}_{4}$, (3) first with $100 \mathrm{ppm}$ as $\left(\mathrm{NH}_{4}\right)_{2} \mathrm{SO}_{4}$ and 5 hours later with $300 \mathrm{ppm} \mathrm{K}$ as $\mathrm{KCl}$, (4) first with $300 \mathrm{ppm} \mathrm{K}$ as $\mathrm{KCl}$ and 5 hours later with $100 \mathrm{ppm} \mathrm{N}$ as $\left(\mathrm{NH}_{4}\right)_{2} \mathrm{SO}_{4}$; an untreated sample was also used.

The samples were incubated at 65 per cent of the W.H.C. and at $29^{\circ} \mathrm{C}$ for 16 weeks. Exchangeable ammonium, nitrate and mineral nitrogen were first determined 24 hours after the preparation of the samples and again 5,8,14, 42, 84 and 112 days later.

Fig. 4 shows that the mineralisation curve of the sample treated with $100 \mathrm{ppm} \mathrm{N}$ as $\mathrm{KNO}_{3}$ runs parallel to and about $100 \mathrm{ppm} \mathrm{N}$ higher than that of the untreated sample. Sixty per cent of the $100 \mathrm{ppm}$ nitrogen added as ammonium was fixed within 


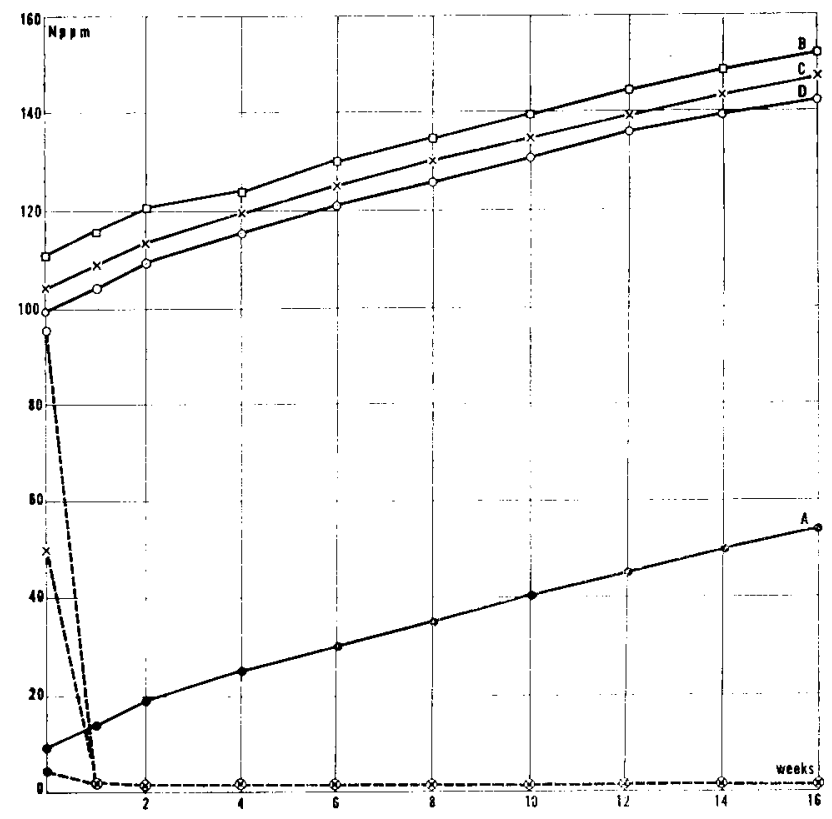

Fig. 3 Total non-fixed mineral nitrogen (solid lines) and exchangeable ammonium nitrogen (broken lines) in a heavy loam soil of the North-East polder either untreated or treated with $100 \mathrm{mg} N$ per $\mathrm{kg}$ of dry soil as $\mathrm{KNO}_{3}, \mathrm{NH}_{4} \mathrm{NO}_{3}$ or $\left(\mathrm{NH}_{4}\right)_{2} \mathrm{SO}_{4}$, and incubated for 16 weeks at $29^{\circ} \mathrm{C}$.

$A=$ untreated soil $; B=$ soil $+\mathrm{KNO}_{3} ; \mathrm{C}=$ soil $+\mathrm{NH}_{4} \mathrm{NO}_{3} ; \mathrm{D}=$ soil $+\left(\mathrm{NH}_{4}\right)_{2} \mathrm{SO}_{4}$.

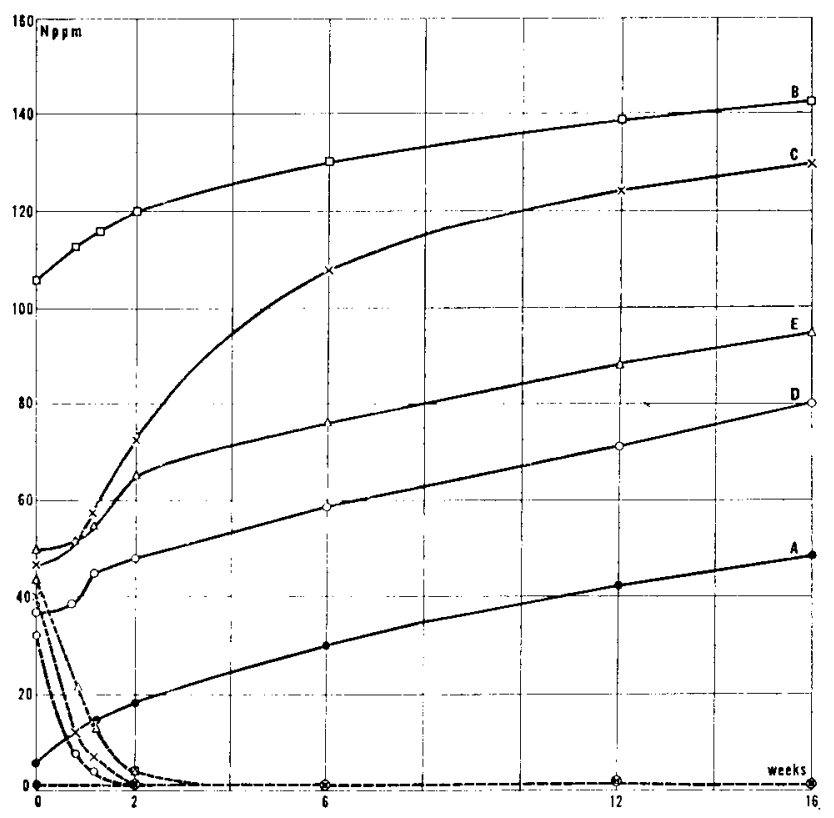

Fig. 4 Total non-fixed mineral nitrogen (solid lines) and exchangeable ammonium nitrogen (broken lines) in a potassium-fixing old river clay from Hedel without potassium fertilizer for 14 years, which was incubated for 16 weeks at $29^{\circ} \mathrm{C}$.

$A=$ untreated soil $; B=$ soil $+100 \mathrm{ppm} \mathrm{N}$ as $K \mathrm{KO}_{3} ; \mathrm{C}=$ soil $+100 \mathrm{ppm} \mathrm{N}$ as $\left(\mathrm{NH}_{4}\right)_{2} \mathrm{SO}_{4}$ $D=$ soil treated with $100 \mathrm{ppm} N$ as $\left(\mathrm{NH}_{4}\right)_{2} \mathrm{SO}_{4}$ and 5 hours later with $300 \mathrm{ppm} \mathrm{K}$ as $\mathrm{KCl} ; \mathrm{E}=$ soil treated with $300 \mathrm{ppm} \mathrm{K}$ as $\mathrm{KCl}$ and 5 hours later with $100 \mathrm{ppm} \mathrm{N}$ as $\left(\mathrm{NH}_{4}\right)_{2} \mathrm{SO}_{4}$. 
Table 4 Amounts of fixed ammonium expressed as percentages of the added amounts of ammonium at different incubation periods found in an old river clay soil of the trial field in Hedel that had not been dressed with potassium for 14 years

\begin{tabular}{|c|c|c|c|c|c|c|c|}
\hline \multirow[t]{2}{*}{ Treatment } & \multicolumn{7}{|c|}{ Incubation period (days) } \\
\hline & 1 & 6 & 9 & 15 & 43 & 85 & 113 \\
\hline $\begin{array}{l}100 \text { ppm }\left(\mathrm{NH}_{4}\right)_{2} \mathrm{SO}_{4} \\
\text { First } 100 \mathrm{ppm}\left(\mathrm{NH}_{4}\right)_{2} \mathrm{SO}_{4}\end{array}$ & 60.0 & 61.7 & 57.8 & 45.8 & 17.9 & 18.5 & 18.1 \\
\hline $\begin{array}{l}5 \text { hours later } 300 \mathrm{ppm} \mathrm{KCl} \\
\text { First } 300 \mathrm{ppm} \mathrm{KCl}, 5 \text { hours }\end{array}$ & 68.2 & 74.8 & 70.0 & 70.9 & 69.9 & 71.5 & 67.9 \\
\hline later $100 \mathrm{ppm}\left(\mathrm{NH}_{4}\right)_{2} \mathrm{SO}_{4}$ & 55.6 & 61.8 & 60.3 & 52.6 & 51.9 & 53.6 & 53.7 \\
\hline
\end{tabular}

24 hours. The mineralisation curve belonging to this treatment has a much steeper slope than those of both the untreated sample and the sample amended with $\mathrm{KNO}_{3}$, so that a considerable amount of the fixed $\mathrm{NH}_{4}+$ was recovered and nitrified during the incubation period. In this respect the illite of the old river clay with no fertilizer potassium for several years differed from that of the young polder soil which retained fixed ammonium against nitrification.

With potassium added, either before or after adding $\left(\mathrm{NH}_{4}\right)_{2} \mathrm{SO}_{4}$, the soil behaved similarly to illite of the young polder soil in that little or none of the fixed ammonium was available to nitrifying bacteria.

An estimate of the amounts of ammonium nitrogen fixed may be got by subtracting the mineral nitrogen in the untreated sample from that in the sample treated with $100 \mathrm{ppm} \mathrm{N}$ after the same period of incubation.

Table 4 shows that fixation of ammonium ions continued for more than 24 hours, as larger values were found in all cases after 6 days. This increase was very small in the soil with only $\left(\mathrm{NH}_{4}\right)_{2} \mathrm{SO}_{4}$ and was maintained for a short period. The amount of fixed ammonium decreased from 62 per cent after 6 days to 18 per cent after 43 days so that about 70 per cent of the amount fixed after 6 days had been nitrified. In the following 70 days the amount of fixed ammonium remained constant, showing that it was not easily released.

The addition of potassium markedly increased the amount of ammonium fixed, more so when potassium was added after the ammonium than when it was added before the ammonium as was also noted by Nômmik (1957) and Jansson (1958). Fixation in the first day was slightly less when potassium was added before ammonium sulphate than with ammonium sulphate alone. Ammonium ions fixed between 24 hours and six days were probably held on the outer surfaces of the crystal lattice so that when potassium was added this small amount of fixed ammonium could be released slowly and nitrified by the nitrifying organisms, whereas that fixed within the first 24 hours was more firmly bound and not available to nitrifying organisms.

A similar experiment was carried out in 1962 with another soil from the experimental field at Nederhemert from a plot given annually $250 \mathrm{~kg} \mathrm{~K}_{2} \mathrm{SO}_{4}$ per ha (Fig. 5). This soil contained much mineral nitrogen $(8 \mathrm{ppm}$ exchangeable ammonium and 62 ppm nitrate nitrogen) and mineralised organic $\mathbf{N}$ rapidly during the incubation.

Curve $\mathrm{B}$ for the soil enriched with $100 \mathrm{ppm} \mathrm{N}$ as $\mathrm{KNO}_{3}$, runs parallel to and above curve $A$ for the untreated soil. In contrast to the soil of Hedel that had not been dressed with potassium for at least 14 years, curve $C$, representing the soil of Nederhemert treated with $\left(\mathrm{NH}_{4}\right)_{2} \mathrm{SO}_{4}$, runs parallel to curves $\mathrm{A}$ and $\mathrm{B}$. In this soil, there- 


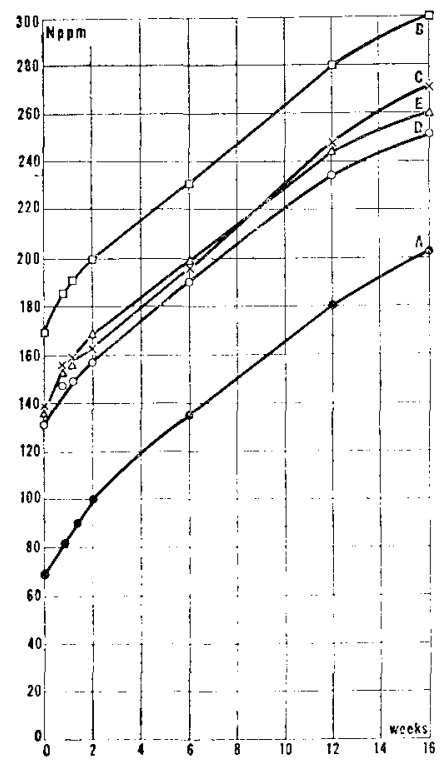

Fig. 5 Total non-fixed mineral nitrogen in a potassium-fixing old river clay from Nederhemert with $250 \mathrm{~kg} \mathrm{~K}_{\mathrm{S}} \mathrm{SO}_{4}$ per ha annually for the last 8 years, incubated for 16 weeks at $29^{\circ} \mathrm{C}$. $A=$ untreated soil; $B=$ soil +100 ppm $N$ as $\mathrm{KNO}_{3}$; $C=$ soil +100 ppm $N$ as $\left(N_{4}\right)_{2} \mathrm{SO}_{4} ; D=$ soil treated with $100 \mathrm{ppm} \mathrm{N}$ as $\left(\mathrm{NH}_{4}\right)_{2} \mathrm{SO}_{4}$ and 5 hours later with 300 ppm $K$ as KCl; $E=$ soil treated with 300 ppm $K$ as $\mathrm{KCl}$ and 5 hours later with $100 \mathrm{ppm} N$ as $\left(\mathrm{NH}_{4}\right)_{2} \mathrm{SO}_{\mathrm{s}}$.

fore, there is no indication of recovery and nitrification of the fixed ammonium. This is ascribed to the annual dressing of potassium applied in the field. Curves D and $\mathrm{E}$ pertaining to the soil amended with both $\mathrm{KCl}$ and $\left(\mathrm{NH}_{4}\right)_{2} \mathrm{SO}_{4}$ also run practically parallel to curves $\mathrm{A}$ and $\mathrm{B}$.

The experiments with the soils of Hedel and Nederhemert clearly show that in the old river clay, nitrification of fixed ammonium nitrogen is hampered by dressings of potassium.

\section{Discussion}

The experiments described above have shown that the young polder soils recently reclaimed from Lake IJssel containing young common (Fithian) illite fix relatively small amounts of ammonium in contrast to old river clay soils containing old open (Ammersooite) illite which are known to be capable of fixing much potassium.

Although the young polder soils fix little added ammonium, the portion they do fix is firmly bound and practically unavailable to nitrifying bacteria for a long period. The availability to nitrifying orgnassms of $\mathrm{NH}_{4}+$ fixed after addition of ammonium salts depends not only on the type of illite, but also on whether it is partly or entirely blocked by potassium. The data in Table 4 suggest that the recovery of fixed ammonium also depends on the site of fixation. Native fixed $\mathrm{NH}_{4}+$ in surface soils is probably more firmly bound and less available to microorganisms and plants than $\mathrm{NH}_{4}+$ that is fixed after adding ammonium nitrogen to the soil. However, the kind of clay minerals, their degree of weathering and the presence of electrolytes play important rôles with respect to the availability of the fixed ammonium to microorganisms and plants.

As $\mathrm{NH}_{4}+$ and $\mathrm{K}+$ ions are considered to be fixed by the same mechanism and in 
about equai amounts (Chaminade, 1940; Page and Baver, 1939; Stanford and Pierre, 1946), the factors influencing potassium fixation, as discussed by Schuffelen and Van der Marel (1955) will also apply to the fixation of ammonium.

The young polder soils of Lake IJssel initially contain much potassium which may decrease considerably in the course of time as a result of absorption by plants and leaching by rain. In the soils of the Wieringermeer polder (reclaimed in 1930) potassium decreased more in the topsoil than in the subsoil (Zuur, 1956). The decrease could be retarded to some extent by applying potassium fertilizers but not prevented. Therefore, the increasing capacity with age of these polder soils to fix ammonium and potassium may be retarded by dressings of potassium, but not wholly prevented. Van Schreven $(1950,1955)$ earlier found that much nitrogen may be lost as ammonia from ammonium containing fertilizers applied to the surface of the calcareous polder soils. Bosma $(1946,1947,1950)$ comparing $\mathrm{Ca}\left(\mathrm{NO}_{3}\right)_{2}$ and $\left(\mathrm{NH}_{4}\right)_{2} \mathrm{SO}_{4}$ for increasing crop yields on such soils concluded from the yield differences that from 20 to 75 per cent more ammonium than nitrate nitrogen was needed to obtain the same increases. The present findings confirm that the less favourable results obtained with $\left(\mathrm{NH}_{4}\right)_{2} \mathrm{SO}_{4}$ are mostly due to volatilisation and very little to fixation of ammonium.

\section{References}

Allison, F. E., Doetsch, J. H. and Roller, E. M., 1951. Ammonium fixation and availability in Harpster clay loam. Soil Sci., 72: 187-200.

Allison, F. E., Kekaufer, M. and Roller, E. M., 1953. Ammonium fixation in soils. 1953. Soil Sci. Soc. Amer. Proc., $17:$ 107-110.

Allison, F. E., Roller, E. M. and Doetsch, J. H., 1953. Ammonium fixation and availability in vermiculite. Soil $\boldsymbol{S}_{\text {ci., }}$ 75: 173-180.

Allison, F. E., Doetsch, J. H. and Roller, E. M., 1953. Availability of fixed ammonium in soils containing different clay minerals. Soil Sci., 75: 373-381.

Bosma, W. A., 1946. De resultaten van de onderzoekingen omtrent de stikstofbemesting in den Noordoostpolder. Verslag Ontwikkelingsdag voor de Landbouwkundige Opzichters. Directie Wieringermeer, Zwolle, 5 : 13-33.

Bosma, W. A., 1947. Proefveldresultaten. Verslag Ontwikkelingsdag voor de Landbouwkundige Opzichters. Directie Wieringermeer, Zwolle, $7: 15-46$.

Bosma, W. A., 1950. Resultaten van stikstofproefvelden. Verslag Ontwikkelingsdag voor de Landbouwkundige Opzichters. Directie Wieringermeer, Zwolle, 11: 34-50.

Chaminade R., 1940. Fixation de l'ion $\mathrm{NH}_{4}+$ par les colloides argileux des sols sous forme non échangeable. Compt. rend., $210: 264-266$.

Cotte, J. et Kahane, E., 1946. Sur une nouvelle méthode de réduction pour le dosage des nitrates. Bull. Soc. Chim. France, p. 542-544.

Hudig, J. and Duyverman, J. J., 1950. De centrale venen van Zuidholland en West-Utrecht. Versl. Landbouwk. onderzoek. $56: 1-96$.

Hudig, J., 1950. Het wezen van de klei. Algem. Ledenverg. Bodemk. Ver. 13 maart Utrecht.

Jansson, S. L., 1958. Tracer studies on nitrogen transformations in soil with special attention to mineralization relationships. Kungl. Lantbruksh. Annaler, 24 : 101-361.

Lees, H. and Porteous, J. W., 1950. The release of carbon dioxide from soils percolated with various organic materials. Plant and Soil, 2 : 231-241.

Marel, H. W. Van Der, 1950. The mineralogical composition of the clay $(<2 \mu)$ separate of the Dutch soils and their cationic exchange capacity. Transacts. 4th Intern. Congr. Soil Sci. (Amserdam), 2 : 92-94.

Marel, H. W. Van Der, 1954. Potassium fixation in Dutch soils, mineralogical analysis. Soil Sci., $78: 163-179$.

Marel, H. W. Van Der and Venekamp, J., 1955. Onderzoek naar het verschijnsel der kalifixatie in de Nederlandse gronden (Potassium fixation in the Dutch soils). Verslagen landbouwk. onderzoek, 61.8: 1-61.

Nômmik, H., 1957. Fixation and defixation of ammonium in soils. Acta Agric. Scand., $7: 395-436$. 
Page, J. B. and Baver, L. D., 1939. Ionic size in relation to fixation of cations by colloïdal clay. Soil Sci. Soc. Amer. Proc., 4 : 150-155.

Russell, E. J. and Hutchinson, H. B., 1909. The effect of partial sterilisation of soil on the production of plant food. I. J. Agr. Sci., $3: 111-144$.

Russell, E. J. and Golding, J., 1913. Investigations on 'sickness' in soil. I. Sewage sickness. J. Agr. Sci, $5: 27-47$.

Russell, E. J. and Petherbridge, 1913. Investigations on 'sickness' in soils. II. 'Sickness' in glasshouse soils. J. Agr. Sci., 5: 86-111.

Russell, E. J. and Hutchinson, H. B., 1913. The effect of partial sterilisation of soil on the production of plant food. II. J. Agr. Sci., $5: 152-221$.

Schreven, D. A. Van, 1950. Loss of nitrogen from ammonia containing fertilizers applied to calcareous soils of the Zuiderzeepolders. Transacts. 4th Intern. Congr. Soil Sci. (Amsterdam), 1 : 259-261.

Schreven, D. A. Van, 1955. Ammoniakvervluchtiging op kalkrijke Zuiderzeegronden bij gebruik van ammoniumhoudende meststoffen. Zwolle, Van Zee tot Land, 11: 1-41.

Schreven, D. A. Van, 1963. Nitrogen transformations in the former subaqueous soils of polders recently reclaimed from lake IJssel. Plant and Soil, $18: 143-162$.

Schreven, D. A. Van, 1964. Stikstofomzettingen in jonge IJsselmeerpoldergronden. Zwolle, Van Zee tot Land, $41: 1-73$.

Schuffelen, A. C. and Mare1, H. W. Van Der, 1955. Potassium fixation in soils. Intern. Potash Institute. Potassium symposium (Rome) : 157-197.

Stanford, G. and Pierre, W. H., 1946. The relation of potassium fixation to ammonium fixation. Soil Sci. Soc. Amer. Proc., 11: 155-160.

Vlassak, K., 1962. Invloed van organische stoffen op de mineralisatie van stikstof in kultuurland. Agricultura, $10: 481-511$.

Waksman, S. A. and Starkey, R. L., 1923. Partial sterilization of soil, microbiological activities and soil fertility: I. Soil Sci., 16:137-158.

Zuur, A. J., 1956. Over het kali- en fosfaatgehalte der Wieringermeergronden. Zwolle, Van Zee tot Land, $16: 1-65$. 